\title{
Article
}

\section{"The School for the Travellers and the Blacks": Student and Teacher Perspectives on "Choosing" a Post-Primary School with a High Concentration of Disadvantage}

\author{
Hannagh Mc Ginley *(D) and Elaine Keane *(D) \\ School of Education, National University of Ireland, Galway, H91TK33 Galway, Ireland \\ * Correspondence: h.mcginley1@nuigalway.ie (H.M.G.); elaine.keane@nuigalway.ie (E.K.)
}

check for

updates

Citation: Mc Ginley, H.; Keane, E. "The School for the Travellers and the Blacks": Student and Teacher Perspectives on "Choosing" a Post-Primary School with a High Concentration of Disadvantage. Educ. Sci. 2021, 11, 777. https:// doi.org/10.3390/educsci11120777

Academic Editors: Michael Shevlin, Richard Rose and Eleni Andreou

Received: 20 June 2021

Accepted: 17 November 2021

Published: 30 November 2021

Publisher's Note: MDPI stays neutral with regard to jurisdictional claims in published maps and institutional affiliations.

Copyright: (c) 2021 by the authors. Licensee MDPI, Basel, Switzerland. This article is an open access article distributed under the terms and conditions of the Creative Commons Attribution (CC BY) license (https:/ / creativecommons.org/licenses/by/ $4.0 /)$.

\begin{abstract}
Since the formation of the Irish State, the participation and attainment in education of members of the Irish Traveller community have been low. In terms of school-related factors, research points to Travellers perceiving the curriculum as irrelevant, experiencing problematic relationships with peers and teachers, a strong sense of not belonging, and low teacher expectations. This paper draws on the findings of a wider study which explored how an intercultural approach to education was conceptualised and enacted, with particular reference to Travellers, in one urban DEIS (disadvantaged) post-primary school in the West of Ireland (St. Greg's) with a highly diverse student population. Located in the interpretivist/constructivist paradigm, and informed by critical race theory, an in-depth qualitative case study research design was employed. Data collection involved twenty-eight semi-structured interviews with teacher and student participants, including Traveller and "other" minority ethnic students, as well as White settled Irish students. Data analysis involved several coding stages, and the development of categories. In this paper, we examine one of the categories, the participants' perceptions of the school as being a school "for the Travellers and the Blacks" and its "reputation" in this regard, as well as the factors impacting the "choice" of the school by different groups of students. Both teacher and student participants were aware of the school's negative reputation and how this was associated with the socio-demographic composition of its student population. Regarded as the school "for the Travellers and the Blacks", it was seen as a "tough" school and one in which academic expectations were low. Choosing St. Greg's was perceived as being related to having a family history of attending the school, not being able to access other schools, and the school providing supports and "freebies". The findings are discussed in the context of previous research, focusing in particular on critical issues of school socio-demographics, reputation, and choice. The paper concludes with observations about the problematic nature of Ireland's increasingly segregated schooling system and recommendations about how the education system might better work to include and support Traveller and other minority ethnic students in post-primary education.
\end{abstract}

Keywords: Travellers in education; school choice; intercultural education; disadvantaged schools; segregated schools

\section{Introduction}

Irish Travellers are an indigenous ethnic minority who fare poorly on every indicator used to measure poverty. They make up less than 1 percent of the Irish population. The Equal Status Act 2000 (Section 2.1) defines the Traveller community as "a community of people who are commonly called Travellers and who are identified (both by themselves and by others) as people with a shared history, culture, and traditions including, historically, a nomadic way of life on the island of Ireland" [1]. Research has consistently shown that anti-Traveller racism is rife in Irish society and is regarded as an almost "acceptable" form of racism [2,3]. This reality also pertains to schools, where Traveller students report high 
levels of racial bullying and discrimination, as well as a lack of a sense of belonging and connection to non-Traveller peers $[2,4,5]$.

Research examining the experiences of Travellers in education has found that Travellers report finding the current curriculum irrelevant [6] and that they perceive that they are treated unfairly by their teachers [7]. In spite of this context, and despite their own reported negative experiences of school, Boyle, Flynn, and Hanafin [5] found that Traveller parents in their study were considerably optimistic about their children's education. However, since the formation of the Irish State, educational participation and attainment for members of the Irish Traveller community have been low [8]. In Ireland, despite very little data on achievement by ethnicity, research shows that Traveller students attendingDelivering Equality of Opportunity in Schools (DEIS) [9] schools have very low scores in English, Reading, and Maths standardised tests in comparison with the general population and "other" minority ethnic groups [10]. (DEIS forms part of the Department of Education and Skills' social inclusion strategy to support children and young people experiencing educational disadvantage in Ireland. Schools included in the DEIS programme receive additional supports in recognition of the proportion of their students from marginalised backgrounds.) While there is almost full participation by Traveller children in primary schools, and a high transfer rate of Travellers to post-primary education, attendance and retention rates remain poor [11]. Data from the Central Statistics Office (CSO) show that Travellers cease their education on average 4.7 years earlier than the general population [12]. Watson et al. [11] reported that only eight percent of Travellers in Ireland had completed their education to Leaving Certificate level in comparison to 73 percent of the general population. Very low numbers completed higher education (115 Travellers by 2011 [13] and 167 by 2016 [12]). In the latest review of the National Access Plan (2015-2019) to widen participation in higher education (HE), it was noted that the target set for Travellers (of 80 Travellers in HE by 2019) had been unmet [14] resulting in Travellers being a central focus of the extended National Access Plan (into 2021) [15].

While diversity has always existed within Ireland, the past three decades have brought rapid social change because of unprecedented inward migration [16]. Consequently, the student population in Irish schools has diversified significantly in this time [17]. However, while the Irish school population has diversified, not all schools have experienced significant changes in their socio-demographic composition. There is a disproportionate number of students from minority and disadvantaged populations in some schools, particularly in DEIS schools [10].

This paper draws on some of the findings of a doctoral study [18] which explored how an intercultural approach to education was conceptualised and enacted, with particular reference to Travellers, in an urban DEIS post-primary school (St. Greg's) in the West of Ireland with a highly diverse student population. There are five sections in this paper. Following this introduction, the literature review examines the nature of marginalisation experienced by Traveller and other minority ethnic students, with a specific focus on schooling. In Section 3, the methodological approach adopted in the study is outlined and information on the research participants is provided. Section 4 presents key findings relating to how the school was perceived by staff and students, and the factors influencing the students in their choice of this school. Finally, in Section 5, the findings are discussed in the context of previous research and the paper concludes with observations about the problematic nature of Ireland's increasingly segregated schooling system.

\section{Literature Review}

\subsection{Minority Ethnic Students' Experiences of Schooling}

Research internationally points to several key themes in the experiences of minority ethnic students in schooling. These include teachers' deficit views and low expectations about certain student groups, and minority ethnic students' experiences of racism in schools.

Deficit racialized constructions of minority ethnic students are commonly reported in Ireland [19-21] and internationally [22,23]. Research from the international context has 
shown teachers frequently view students from marginalised and minority groups through a "cultural deficit lens" [24] often perceiving minority students to be weaker students [23], and holding low expectations based upon assumptions of Black inferiority [22]. Further, minority students are viewed by teachers as "undesirable" learners [25], including in relation to their behaviour [26-28]. In Ireland, Devine's [29] study demonstrated teachers' particularly negative view of Roma and African students with respect to their academic ability and behaviour in school (see also [30]). Frequently, such negative constructions of minority ethnic students' ability are related to perceptions of English language proficiency and (perceived) related language support needs [31,32], as for many students of immigrant "origin" in schools, English is an additional language. For example, Ní Dhuinn and Keane [19] reported that their (migrant) minority ethnic participants' academic ability was constructed by their teachers in deficit terms, connected to (usually incorrect) assumptions about their proficiency in English. Further, many of the participants reported not being encouraged to progress to higher education.

In the socio-relational realm, research is clear that minority ethnic students experience problematic peer relationships. This is evidenced in a lack of mixing between groups [33,34], and in majority group students' deficit views of their minority peers' academic ability [22]. Racism, discrimination, and harassment in schools is also evident in peer interactions [35], although it is frequently downplayed or denied [36]. Similarly, research in Ireland has found evidence of a lack of meaningful mixing between student groups, as well as forms of inter-ethnic conflict [4]. Further, it has been found that minority students are viewed as undesirable learners by their peers [21], resulting from their construction as "other" with respect to their skin colour, cultural background, and/or first language and related perceived language "deficits" $[3,17,21]$. Additionally, students of migrant origin frequently have their "Irishness" questioned and experience challenges in their understanding and presentation of self in terms of their identity [19,21,37]. Ní Dhuinn and Keane [19] found that despite explicitly self-identifying as Irish (and in some cases having Irish citizenship), their migrant minority ethnic participants were positioned by their White Irish peers as not Irish, particularly where their skin colour was other than White. In this regard, they emphasised (White) Irish students' exclusionary constructions of Irish identity.

In terms of Travellers specifically, in the UK, "Gypsy and Traveller" (GRT) students have been identified as "the group most deprived of formal education in the country" [38] p. 265. Similar to Ireland, where only 13 percent of Traveller children complete their postprimary school education in comparison with 92 percent of the general population [11], early school leaving among Travellers remains high. Explanations for early school leaving are usually framed within the context of "push" and "pull" factors [39]. Push factors identified in the literature include being subjected to racism and racially motivated bullying from both students and teachers; the irrelevance of the curriculum; low teacher expectations; and exclusion $[40,41]$. The pull factors usually identified reference "cultural norms", such as the tendency to marry young and the lure of the Traveller economy (i.e., the economic activities in which Travellers have traditionally engaged, which are "'outside' dominant or 'mainstream' economic activity that is based on sedentary modes of production" [27,42] p. 13. Additionally, nomadism has been identified as one of the key reasons for Travellers' poor attendance at school and low achievement levels [43]. While some of the reasons why Travellers leave school early may be linked to pull factors, research has found that it is more likely due to push factors, "such as exposure to racist bullying, social disengagement, educational policy and low teacher expectations" [39] p. 360 as well as isolation, poor relationships with their teachers and peers, low teacher expectations, and an overall lack of support $[39,44]$. Kavanagh [45] found that while teachers were empathetic towards Travellers, they tended to adopt a cultural deficit lens and blamed Travellers for the inequalities that they experienced. Research also points to the "White racism" [41] experienced by GRT groups, including racist bullying [44,46]. It has also been found that teachers do not always believe GRT students when they report racist bullying [47], and Traveller parents' concerns in this regard often underpin their reasons for not sending their children to school [39]. 
Research also has found that teachers frequently view Traveller students as unruly and disruptive and frame Traveller culture as abnormal [41]. According to Derrington [39] p. 357, Traveller students rely "on maladaptive coping strategies to deal with psychosocial stress associated with cultural dissonance and social exclusion", including fight (physical and verbal retaliation), flight (leaving school), and "playing white" (hiding identity). Playing white or wearing "white masks" [48] (i.e., hiding their ethnic identity) is a common tactic employed by children from minority groups to deal with the impact of racism.

Research in Ireland has demonstrated that negative attitudes toward minority ethnic groups are prevalent among the Irish public, most especially towards Travellers [3,29,49]. For example, Tormey and Gleeson [3] found that 42 percent of the 4970 post-primary school students that took part in their study reported high or very high levels of "social distance" from Travellers. Lynch and Lodge [49] reported that three-quarters of the post-primary school students participating in their study believed that Travellers would not fit in to their school. Kavanagh [45] points out that teachers often fail to recognise the inherent racism in non-Traveller parents asking teachers to move their children away from Traveller children. This is perhaps unsurprising when one considers that Travellers were not recognised as an ethnic group in the Republic of Ireland until 2017, instead, being viewed as a "sub-culture" within Irish society. In this regard, Kitching [50] p. 177, uses the lens of critical race theory (CRT) to explain the educational inequalities experienced by Travellers, and criticises liberal anti-racist discourse for "failing to meaningfully interrogate race and racism in globalised Ireland beyond a white/non-white binary".

The absence of Traveller history and culture in the school curriculum is also a factor in Traveller students' perceptions of curriculum irrelevance and in feelings of not belonging [46,51]. Following the recognition of the Traveller community as a distinct ethnic group in March 2017 by the Irish State, the "Traveller Culture and History in Education Bill 2018" aims to provide for the inclusion of Traveller culture and history in the curriculum in State schools within the framework of the 1998 Education Act. While this is an important development, Kavanagh and Dupont [52] rightly note the difficulties associated with "additive" curricular amendments, including, for example, issues of tokenism, and the danger of not critically attending to the role of teachers (including in terms of their positionalities) in perpetuating inequities. Further, it is clear that careful and critical continuous professional development for teachers will be required to ensure that Traveller culture and history are taught in an appropriate and sensitive manner [18].

\subsection{School "Choice" and Access to Schools}

There are three types of post-primary schools in Ireland: voluntary secondary schools (mainly founded by religious orders), vocational schools, and community/comprehensive schools. Additionally, there are a small number of private fee-paying schools [53]. Vocational schools were established to cater for the perceived needs of students from lower socio-economic backgrounds, and in that context, they have provided a broad curriculum with a more practical than academic focus [53]. The different school types vary greatly in terms of the socio-economic composition of their student populations. While there tends to be a higher concentration of working class and "lower ability" students in vocational schools, middle class and "higher ability" students are over-represented in voluntary secondary schools [16]. Indeed, there is evidence of segregated schooling in Ireland, with Black and other ethnic minority students, including Travellers, over-represented in larger, urban DEIS schools [16]. Typically, these schools are under-subscribed and have a significant concentration of students from disadvantaged backgrounds [10]. As noted by Ní Dhuinn and Keane [19], in part this is a result of school enrolment policies which disadvantage newly arrived and Traveller families with respect to access to schools.

The right to choose a school is enshrined in the Irish constitution; however, the extent to which families can "choose" a school to attend is mediated by their socio-demographic positionality. Not everyone can engage in the same way with choice processes [16,49]. Indeed, for Skeggs [54] p. 139, "choice is a particularly middle-class way of operating in 
the world", and middle-class parents are found to possess "greater insider knowledge of the education system" [55] p. 59 which inevitably impacts their ability to navigate the education system and decision-making therein. For many-especially for some minority and lower socio-economic groups-educational and schooling pathway choices are highly constrained $[49,55,56]$. Travellers frequently encounter difficulties when attempting to enrol their children in certain mainstream schools. In the UK, admissions criteria for entry to post-primary level can be based on primary school attendance [57], which results in some Traveller children being denied access. Bhopal [41] found that some schools are reluctant to admit students that they perceive to be disruptive and aggressive because they may affect the schools' position in league tables, or in the case of Traveller students, the school's "reputation". Levinson [58] has reported that some parents boycott schools that admit Traveller students.

In Ireland, admission policies often serve to exclude Travellers [2] and other minority and disadvantaged students. Under the Education Act, 1998, and the Equality Acts 2000-2004, schools are required to have a school admissions policy that respects the principle of equality and provides for maximum accessibility to the school; schools may not discriminate in relation to admission, access, participation, or expulsion. Despite these policies, schools have been found to employ discriminatory practices in terms of their enrolment policies, including the requirement to be from a particular religious background or catchment area, the length of time on the waiting list, or the "sibling clause", which allows for the prioritisation on waiting lists of children who have a brother or sister already enrolled in the school [2]. In the recent past, the "Catholic first" clause meant that schools could prioritise students from Catholic backgrounds [59]. In July 2018, the Equal Status Act (2000) was amended, and schools were prohibited from using religion as a barrier in over-subscribed schools. While the Education (Admission Policy) Act (2018) prohibited schools from charging fees (except in the case of fee-paying schools), related legislation has done nothing to address the "hidden" monetary barriers such as the requirement for expensive equipment, uniforms, or financial contributions from parents [60]. Because of the segregated model of education for Travellers that existed in the past in Ireland, Traveller children are often automatically excluded because they cannot meet the family history criterion [61]. Children from working class and immigrant backgrounds are also excluded from certain schools because their families would not have had a "tradition" of attending the more prestigious schools. Challenging such exclusionary policies is exceptionally difficult as was discovered by the Irish Traveller family who took a case against a school that would not enrol their son in 2010 [61]. In 2020, new school admission policies were announced by the Minister of Education, which require that schools accept all applicants, where schools are not over-subscribed, and that schools no longer employ waiting lists past a certain amount of time.

Research suggests that there are "good" schools and "bad" schools, at least in the public's perception [62]. As "places also mean people" [63] p. 160, students attending bad schools become labelled accordingly. In Ireland, the media fuels public perceptions of schools by publishing detailed accounts of which schools (and therefore, which students) are "succeeding" and "failing" via the "league tables" which provide information on the "best" and "worst" performing schools in terms of their students' Leaving Certificate results and progression rates to higher education. Many DEIS schools feature towards the bottom of such tables, and in spite of some improvements over time on certain markers of achievement, research has consistently pointed to the significant achievement gap between DEIS and non-DEIS schools [64,65]. This paper examines issues pertinent to the above discussion of the literature, examining teacher and student perceptions of a highly diverse urban DEIS school as being a school "for the Travellers and the Blacks", along with issues concerning the school's reputation and the role of Traveller students therein, and factors impacting the "choice" of St. Greg's by different categories of students. 


\section{Methodology}

There has been relatively little research in Ireland examining Travellers' experiences of education. While two qualitative studies are notable [5,7], the former focused on Traveller parents' involvement in Traveller pre-schools and the latter explored adult Travellers' reflections on their past experiences of education. This paper draws on data collected as part of a wider in-depth qualitative research project [18], which adopted a case study approach in one urban, DEIS post-primary school in the west of Ireland (St. Greg's), with a high concentration of disadvantage in terms of its highly diverse student population. The objective of the study was to examine how an intercultural approach to education was conceptualised and enacted in an urban, DEIS post-primary school context, with particular reference to Traveller students and their experiences.

Methodologically, the study was located in the constructivist/interpretivist paradigm, which emphasises participants' understandings and meanings, and the socially constructed nature of "reality". From this paradigmatic standpoint, there is a concern with the individual and subjective experience; therefore, understanding the social world from participants' perspective is emphasised [66]. Additionally, the role of the researcher in the research, their interaction with participants and data, and the need for significant reflexivity in this regard is highlighted [67]. However, the interpretivist/constructivist paradigm has been criticised for not adequately addressing issues of social justice [68], with critics emphasising the need for research to transform "the lives of the participants, the institutions in which people work or live, and the researcher's life" (ibid. p. 9). In this context, the study also drew significantly on critical race theory (CRT) [69-71], which offers new and radical ways to conceptualise the role of racism in education and provides a framework for challenging the embeddedness of racial inequity [72]. Key tenets of CRT include the centring of racism as a unit of analysis, and the belief that racism is "normal" and not aberrational in society [73]. CRT stresses the need to understand racism within its social, economic, and historical context [41]. Bell's [69] theory of "interest convergence" is another hallmark of CRT; it is argued that Whites will only advance the cause of racial justice when doing so coincides with their own self-interest and is of benefit to them [74]. White privilege and supremacy are core foci in relation to how structural and institutional systems of superiority and subordination are created and maintained [72,75]. CRT emphasises storytelling and counter storytelling, which is regarded as having the potential to disrupt hegemonic "taken-for-granted" myths and assumptions, by presenting analyses from the perspective of minority group members [73].

CRT informed this study from the outset in terms of the focus of the research and various aspects of the methodological approach employed. CRT understands that there are many ways of interpreting the world [76] and calls for the inclusion of minority perspectives to challenge hegemonic taken-for-granted myths and assumptions about what is considered normal [73]. Presenting stories about discrimination from minority perspectives is a primary objective of CRT [77]. In this regard, minority students from diverse backgrounds, as well as teachers, were included and prioritised in the study. Additionally, by using critical autobiography and reflexive journaling as a form of counterstorytelling, researcher identity and positionality, and their impact on the research process and data, were key foci throughout the research [18].

The study was conducted in an urban DEIS post-primary school in the West of Ireland with a highly diverse student population and a significant concentration of students from disadvantaged backgrounds. While initially a comparative study was planned to examine the ways in which an intercultural approach was being implemented in different school contexts, for example in DEIS vs. non-DEIS school contexts, access to schools proved highly problematic — particularly as a Traveller researcher [18] — and ultimately the research was conducted as part of a case study design in one school. Following several meetings between the Traveller researcher and the school Principal and teaching staff, gatekeeper (Principal) consent to conduct the study in the school was obtained. 
All staff were invited to participate and provided with information sheets and consent forms. In terms of student participant recruitment, the Traveller researcher visited classes in the school to explain the study, and relevant groups were invited to participate, with letters of invitation, information sheets, and consent forms sent to their parents. As anticipated, due to low literacy rates among the Traveller community, additional measures were needed to recruit students, including relaying information about the study to Traveller parents through researcher contacts in the Traveller Movement and Primary Health Care in the community. In such contexts, where literacy is an issue and potential participants may not have the skills to engage with documentation, researchers must find other ways of ensuring that potential participants understand what they are being asked to consent to [78]. Additionally, the presence of a Traveller researcher in the school generated a lot of attention from Traveller students, who approached the researcher and expressed interest in participating. The researcher also visited classes in the school to explain the study and invite participation. The children whose parents returned signed consent forms were included in the study.

Data collection involved 28 semi-structured interviews, 9 with staff participants (SPs), including the principal, deputy principal, and 7 teachers; and 19 with student participants, including 9 Traveller student participants (TSPs), 6 non-Traveller minority student participants (MSPs), and 4 white Irish student participants (WISPs). Full ethical approval was provided by the Research Ethics Committee at NUI Galway. Table 1 provides details of the study's participants.

Table 1. The study's participants.

\begin{tabular}{|c|c|c|c|}
\hline & Pseudonym & Sex & Participant Group \\
\hline 1 & Barry & Male & Principal \\
\hline 2 & Caroline & Female & Teacher \\
\hline 3 & Clodagh & Female & Teacher \\
\hline 4 & Padraic & Male & Vice-Principal \\
\hline 5 & John & Male & Teacher \\
\hline 6 & Kathy & Female & Teacher \\
\hline 7 & Ruth & Female & Teacher \\
\hline 8 & Sarah & Female & Teacher \\
\hline 9 & Sean & Male & Teacher \\
\hline 10 & Jennifer & Female & Traveller Student (5th Year) \\
\hline 11 & Connie & Male & Traveller Student (5th Year) \\
\hline 12 & Mickey & Male & Traveller Student (2nd Year) \\
\hline 13 & Richard & Male & Traveller Student (2nd Year) \\
\hline 14 & Celine & Female & Traveller Student (3rd Year) \\
\hline 15 & Rosa & Female & Traveller Student (2nd Year) \\
\hline 16 & Serena & Female & Traveller Student (3rd Year) \\
\hline 17 & Paddy & Male & Traveller Student (1st Year) \\
\hline 18 & Theresa & Female & Traveller Student (5th Year) \\
\hline 19 & Johnathan & Male & White Irish Settled Student (6th Year) \\
\hline 20 & Hayden & Male & White Irish Settled Student (5th Year) \\
\hline 21 & Jason & Male & White Irish Settled Student (2nd Year) \\
\hline 22 & Connor & Male & White Irish Settled Student (3rd year) \\
\hline 23 & Victoria & Female & (Non-Traveller) Minority Student (5th Year) \\
\hline 24 & Josef & Male & (Non-Traveller) Minority Student (5th Year) \\
\hline 25 & Christiano & Male & (Non-Traveller) Minority Student (6th Year) \\
\hline 26 & Marian & Female & (Non-Traveller) Minority Student (3rd Year) \\
\hline 27 & Natalia & Female & (Non-Traveller) Minority Student (2nd Year) \\
\hline 28 & Holly & Female & (Non-Traveller) Minority Student (5th Year) \\
\hline
\end{tabular}


The student interviews were approximately 30-45 min in duration. Interviews with staff participants were approximately one hour in duration. All interviews were audiorecorded and transcribed verbatim. Soft copies were emailed to the teacher participants for their review. Given the sensitive nature of the data generated, and the low literacy levels of some of the student participants, those who wished to review their transcripts were offered an opportunity to meet with the researcher to read the document together at a time and in a venue that suited them. Five of the nineteen student participants (three of the nine TSPs and two of the six MSPs) took up this offer to meet and all meetings took place in the school. All the staff and student participants who reviewed their transcripts subsequently agreed that the transcripts accurately reflected their interviews and only very minor changes were requested.

Data were analysed through a series of stages, which commenced with immersion in the data by reading and re-reading transcripts, and re-listening to the audio-recordings. Next, the transcripts were coded line by line, using Charmaz's [79] "open coding" approach, before progressing to more focussed coding which involved reviewing all the initial codes and bringing forward the most significant and/or frequent ones (ibid.). Following the lengthy initial coding process, provisional categories were developed by grouping together similar codes, and subsequently refined through mapping exercises and elements of thematic analysis [80]. From the perspective of CRT, attention was paid to the intersectionality of class and gender with race, whilst maintaining the central focus on race and ethnicity, and on how racism shaped the experiences of Traveller students.

Four major categories were developed [18], and this paper focuses on one, the participants' perceptions of the school as being a school "for the Travellers and the Blacks" and its reputation in this regard, as well as the factors impacting the choice of St. Greg's by different categories of students.

4. Findings: The School for the Travellers and the Blacks: Reputation, Lived Realities, and "Choosing" St. Greg's

In this section, we discuss the reasons influencing school choice from the perspectives of the student participants, examining how they viewed their school, and their beliefs about how their school was perceived by the wider community. Students' perspectives on "choosing" to attend St. Greg's are compared to teacher participants' views on the school's socio-demographic context.

\subsection{Reputation' and Lived Realities}

The staff participants (SPs) and the student participants from the different groups all mentioned that St. Greg's had a bad reputation. However, there was some variation between the participants from different groups regarding the reasons for the school's negative reputation. Many of the SPs believed that there was "a stigma attached to the school" (Barry, SP) because of its diverse student population. John (SP) believed that St. Greg's was seen locally as "the school for the Travellers and the Blacks".

Like if you talk to any [locals] ... they say this school is for Travellers and Blacks and that is the stigma we have. It is very hard to change it. (John, SP)

The MSPs and TSPs believed that having a large Traveller population was the main reason for the school's bad reputation. The MSPs recalled being told negative stories about the school and hearing that it was "really rough" (Marian, MSP). As a result, they expected to "get beat up" (Joseph, MSP) and were nervous about attending the school:

Yeah, a lot of Travellers come here, so they would kind of be thinking, this school must be bad. That is what I heard anyway. But I never thought it was that bad to be honest. I really like the school. (Christiano, MSP)

I think because a lot of Traveller people come here. And they [Travellers] have a bad reputation for lots of fighting and stuff, but I think within every culture there 
is going to be people like that, in every school there is people like that. (Holly, MSP)

Anyways, people were saying, 'oh that that school, like ehm, that school is full of Travellers, you get beat up, First Year is that bad'. (Joseph, MSP)

Some of the MSPs talked about being warned about the school being "rough", and some felt "fearful" (Natalia, MSP) of encountering Travellers. However, after joining the school, they described it as being a "really nice place" (Marian, MSP) and "not as bad as everybody says" (Josef, MSP), and they were glad to discover that Travellers were "not that scary" (Marian, MSP).

While the WISPs did not mention being fearful about attending St. Greg's, they did hint at it having a reputation for being a bit of "a hard school" (Johnathan, WISP) and some indicated that they also blamed Travellers for the school's negative reputation. Hayden (WISP), for example, was clear that he had "learned to avoid them [Travellers]".

I don't know, you have some kids that you stick away from because trouble starts and stuff like that. That is about it really ... Mostly Travellers, who start everything. Anything they can start on they will just start on. I have learned to avoid them. (Hayden, WISP)

Two of TSPs also highlighted issues to do with the school's reputation. Both Rosa and Richard mentioned that their parents were worried about them attending St. Greg's because of its reputation in relation to students smoking or having boyfriends or girlfriends. While Rosa did not link Travellers to St. Greg's poor reputation to Travellers, she was conscious of the negative ways in which Travellers were perceived in society:

... they view Travellers ... how would I say, me, always in trouble, always drinking, robbing, stealing, dressed naked, wearing a lot less clothes like, and mean to people ... You don't learn that you just know that, like. The way people look at you, like. (Rosa, TSP)

Some of the MSPs opined that St. Greg's had a bad reputation because it was "full of dummies" (Josef, MSP) and did not score high on the league tables.

And some people were like, that is a school full of dummies, they don't really go to school, they just go dossing, and it is really not all of us who go dossing. (Josef, MSP)

... if you went there, you would never do well, that you would never go to university. Ehm, you wouldn't progress in life. You would just stay at the same level, and you would become the same as everybody else who went there, supposedly. (Holly, MSP)

The SPs believed that the students at St. Greg's were "a lot tougher" (Sarah, SP) to teach because they "came from very difficult backgrounds" (Ruth, SP), had "genuine problems" (Sarah, SP), and "much more challenges" (John, SP) than students in "most other schools" (Sarah, SP). The SPs identified poverty, addiction, homelessness, and domestic violence as issues affecting the students at St. Greg's.

... a lot of our students come from very difficult backgrounds ... a lot of them might not even have had breakfast in the morning ... there are a lot of underlying factors there. (Ruth, SP)

... it depends on the home. It can be problems with alcohol, problems with drugs, can be members of families in prison, parents can be in the shelter, because of domestic violence, quite regularly, and sometimes for long periods of time ... we would have several parents that would have experienced homelessness ... there may be even queries about neglect. (Kathy, SP)

The SPs described the young people at St. Greg's as "just living day to day" (John, $\mathrm{SP})$ compared to students in other schools who came from homes where "they are fed and watered" (John, SP), were "motivated" (Barry, SP), and had "aspirations" (John, SP): 
... But they [students in other schools] are motivated. They have aspirations.

They know where they want to go to. Some of our kids are just living day to day and going from week to week. They don't think about the future ... (John, SP)

For the SPs, St. Greg's was an enjoyable though often quite challenging school in which to work. As John (SP) remarked, "some days it is a really great place to work and other days you are going home saying 'Jesus, I need to get some place else'". They explained how they had learnt "to readjust" their "expectations" and to stop "driving beyond what the kids were willing to put up with" (Barry, SP). John explained further, noting that he "had to adapt to the school and environment" and suggested that you could not be too "heavily academic" if you wanted to "survive" as a teacher in a school like St. Greg's.

I found it harder to readjust my expectations ... I kept driving beyond what the kids were willing to put up with ... I went straight into a classroom expecting, look at, these are all going to be Engineers and Doctors ... That didn't go down well at all ... I suppose my expectation came down a small bit, I became more realistic ... You are not dealing with the same thing at all here. You have to be more open minded about the difficulties with these kids. They are great to be coming in at all, some of them. That is a reality. (Barry, SP)

In here, we have the laugh with them all of the time you know. There is give and take. There is a lot of joking and banter all of the time, but you have to otherwise you are not going to survive in here. Not a notion ... If it is too heavily academic and you take yourself too seriously you will struggle ... You know you adapt to the school and the environment that you are in. (John, SP)

\subsection{Choosing St. Greg's}

Given St. Greg's 'rough' and challenging reputation, what were the student participants' reasons for choosing this school? Three main reasons were offered by the student and staff participants: (1) family history of attending St. Greg's, (2) not being accepted by other schools, and (3) the availability of supports and "freebies".

\subsubsection{Family History of Attending St. Greg's}

Both the SPs and the TSPs highlighted a family history of attending the school as being a key factor for Travellers deciding on St Greg's. Clodagh (SP) pointed out that Traveller students felt "very safe" and "comfortable" in the school as they were surrounded by members of their own community:

They come, they come, they come, they are surrounded by their friends, their neighbours, or whatever cousins they have, it is very safe for them, it is very comfortable. (Clodagh, SP)

Mickey (TSP) pointed out that having a family history of attending St. Greg's meant that he "didn't really choose" the school in any active sense:

This school? I didn't really choose because all my cousins were coming here and everything and my uncles came here. (Mickey, TSP)

Family history was also a factor for some of the non-Traveller student participants. Johnathan (WISP) said that the "only reason" he attended St. Greg's was "because [his] my brother was in there". Jason (WISP) indicated that having a history of family attending St. Greg's also influenced his choice because it made him believe he "had a better chance of getting in". Jason's cousin attended one of the more affluent non-DEIS schools for a time but had been expelled.

\subsubsection{Not Being Able to Access, or Not Being Accepted by, Other Schools}

Several of the student participants reported that they had not been accepted by other schools, or else had felt that they could not apply. Christiano (MSP) had applied to two 
other schools that he would have preferred to attend and did not know why he had been rejected: "I don't know what the problem was, I just got rejected, I don't know what the reason was". He went on to say that his Irish-born stepfather knew why he was rejected but he did not elaborate when probed and observed that "it doesn't really matter, because I didn't get in there" (Christiano, MSP).

Having to be "smarter" to get into other schools was something that several of the student participants believed to be an issue. For example, Marian (MSP) believed that other schools did not accept the "people that are stupid":

Oh yeah, because maybe they don't accept all of the other children, but like St.

Greg's do because there is a lot of people in [other school] and they don't accept most of the people that are stupid. (Marian, MSP)

Similarly, Jason (WISP) cited not being "that smart" as the reason why he had not applied elsewhere. He also remarked that "there is not that many coloured people" in other schools and believed that for a "coloured" person to be accepted into other schools they would have to be "really smart".

Three of the WISP student participants expressed a preference to attend another school and felt they would leave St. Greg's given the opportunity. While Jason (WISP) believed that he did not stand a chance of being accepted into a specific other school, he emphasised that he would "love to go to that school now" because he believed it was a better school where "they actually have to try to educate you".

When I was younger, I thought it was all gay and all that but now I just want to go to it because most people I know had to get a better education to get in, to get a job and all that ... because it is like, they are stricter and everyone says, 'oh it is better, they have to actually try to educate you'. (Jason, WISP)

Both the MSPs and TSPs seemed satisfied, indeed happy, with being at St. Greg's and none of them expressed a desire to leave. Indeed, some of the TSPs had left what would be considered "better" schools to attend St. Greg's. For example, Theresa (TSP) decided to leave the better school because she preferred to be amongst more Travellers:

[re. old school] It is a good school, but just I would prefer to be around more people, more Travellers. There was only the one Traveller in the school, like, that I really talked to. There was more Travellers in St. Greg's. (Theresa, TSP)

The students were also conscious of the role of waiting lists in being able to access certain over-subscribed schools. For example, Johnathan (WISP) believed he would not have been accepted in the school that he wanted to attend because "a load of people try and get into that school, so like ... you would have to sign up like in 5th class". In the same way, the student participants were conscious of schools' admissions policies. On this issue, Jason (WISP) praised St. Greg's approach to enrolment, noting that they "let everyone into the school ... no matter where they are from, their race or anything", because he did not feel other schools took the same approach.

The SPs felt that "academic performance" was considered something that was "not top of the list" (Roisin, SP) for Traveller parents, or the "number one priority" for parents of students in St. Greg's in general, when it came to school choice. The SPs were also very aware of schools' differing approaches to enrolment. For Padraic, school admission policies were being used "to protect the standard of education" ... the other side is they are really protecting is the standard of education and the standard of the system ... I don't like it, the elitism that goes on in some schools ... they just pick the best 150, so why wouldn't they be at the ... top of the league. If they said, right pick the first 150 that comes in, that would be a different story. (Padraic, SP)

Some of the SPs felt that it was unfair and elitist that other schools were not being made to "take their fair share" (John, SP) of students from diverse backgrounds. Similarly, Clodagh (SP) felt that "the ground needs to be levelled there completely to be fair to 
everybody's needs". For the staff, St. Greg's abided by its mission statement of inclusivity and did not "cherry pick" (Padraic, SP) like other schools which they felt often paid "lip service to open door policies" (Clodagh, SP).

But I do think what tends to happen is our school is the school in ... that takes the vast majority of them [students from diverse backgrounds]. We don't cherry pick. We abide by our mission statement. We are probably the most inclusive school within the area so we can never be accused of being discriminatory. (John, SP)

People pay lip service to open door policies, we don't. We have an admissions policy and it is crystal clear and it always has been. You know, we don't refuse anybody ... But there are others who say they have open door policies, in Christian schools as I call them, and the opposite is true. (Clodagh, SP)

Some of the SPs mentioned that "other schools use money as a barrier" (Clodagh, SP) to access, requiring parents to pay large amounts for resources and/or extra-curricular activities: "if you enrol here, we want 300 pounds for photo-copying and we need it for sport". John (SP) suggested that a "new school" that had recently opened in the area was "redirecting students" to St. Greg's and "telling any Traveller that rings up 'no, we are not a DEIS school, and we don't offer free books and we don't do free lunches'".

\subsubsection{Extra Supports, Subject Choice, and Freebies}

While not mentioned by any of the student participants, some of the SPs suggested that students from minority groups attended St. Greg's because of the wide subject choice and extra supports available to them. Sean (SP), for example, argued that the "international students" preferred attending St. Greg's because of all the support that was available in the school.

International students come here because we have a lot of support for international students ... In terms of extra English, languages, there is a tradition of being able to sit the Leaving Cert in your own traditional language through Polish or whatever. (Sean, SP)

Not all the SPs, however, were convinced that the extra supports or subject availability were motivating factors for school choice. Barry (SP), for example, pointed out that many schools offered the same range of subjects as St. Greg's:

I mean some people will say, look it, we want to come to the school because of the subject choice. Well, look it, at the end of the day, we are traditionally a vocational school, and we do have a heavy practical background, but all the schools offer Woodwork and Technical Drawing. And Art, and any of these anymore. So that is not going to ... We are not going to stand out just for doing those subjects. (Barry, SP)

Some of the SPs cited "getting freebies" as a motivating factor for parents in deciding on St. Greg's. It was evident that some of them believed this to be the case particularly for the parents of Traveller children. Caroline (SP), for example, specifically mentioned that Travellers attended the school because "they get everything for free".

Because we are a DEIS school, everything is free. We have the book scheme and the lunches, and all the resources are free. We don't have to pay for anything. They [Travellers] get all of these trips and everything. (Caroline, SP)

Well, I would say that the biggest issue is the whole financial side of it. I know the new school that has opened above is ... they are telling any Traveller that rings up 'No, we are not a DEIS school, and we don't offer free books and we don't do free lunches'. (John, SP)

While all the student participants mentioned that they got a lot of things for free, such as trips and lunches, only one of them, Josef (MSP), mentioned hearing about getting "free 
lunches" in St. Greg's before he had joined the school. However, he was more concerned about the school being a "rough" place than getting stuff for free.

... But [friend], he actually went to this school. Like and other people who weren't in the school were like, 'Oh yeah, this is going to happen, this is going to happen' but [friend] he just, he made loads of friends here and I was, like, 'I thought this school was meant to be rough?' and he was like, 'no, it is not that bad, if you do your own good, like, you will be fine. The teachers' pay attention to you, you get free lunches, it is a really nice place, like'. (Josef, MSP)

The other student participants did not mention being motivated to attend the school because of its DEIS status and the expectation of 'freebies'. Indeed, many of them complained about the quality of the food on offer and tended to bring in their own food or buy lunch from the local shops.

\section{Discussion and Conclusions}

Both staff and student participant groups from St. Greg's were aware of the school's bad reputation and how this was associated with the socio-demographic composition of its student population. Regarded as the school "for the Travellers and the Blacks", it was seen as a tough school and one in which academic expectations were low. Choosing St. Greg's was perceived as being related to having family history of attending the school, not being able to access other schools, and St. Greg's providing supports and freebies.

\subsection{School Socio-Demographics, Reputation, and Academic Expectations}

In the UK, urban schools are often assigned inferior status because of their high concentration of minorities [81]. Similarly, now in Ireland it seems that some DEIS schools are perceived as "inferior" because of a high concentration of "Travellers and the Blacks" (John, SP) and other minorities and marginalised groups. While one-third of St. Greg's student population was made up of White settled Irish students from disadvantaged backgrounds, one third comprised (non-Traveller) minority ethnic students, and one third Traveller students, an unusually high number. While high levels of diversity are not unusual in DEIS schools $[82,83]$, some DEIS schools are more diverse than others.

Research has suggested that a school with a diverse student population may be viewed in a negative light by teachers, parents, and students, if the diverse students are also from socio-economically disadvantaged backgrounds $[84,85]$. While none of the student participants from the different participant groups attributed the school's negative reputation to their own socio-economic or ethnic group, they were acutely aware that their school was positioned within a "demonised school" discourse ([86]; see also [82]). Hollingworth and Archer [81] found that demonised school discourses are often resisted and contested by young people, and in this study, some of the student participants resisted the stigmatised view of their school. Students from certain backgrounds are seen as a "risk" to the reputation of a school [87] and this study found that Traveller students posed a risk from the perspective of all participant groups, except the Traveller participants themselves, although they were aware of how, as a group, they were perceived in society. As Bryan [87] argues, macro processes and discourses impact negatively at the school level and upon ethnic minority students, and this was seen in the current study with some of the non-Traveller minority ethnic student participants being "fearful" (Natalia, MSP) of encountering Travellers, although they subsequently found that they were "not that scary" (Marian, MSP). In a sense, what is described here is a process of "demystification" of this negatively stereotyped group through "the figured world" of the school ([86] p. 386). Research suggests that when groups encounter each other, relationships improve [11] because myths are dispelled and the "other" becomes more familiar. While the WISPs referenced the school's reputation as a "hard school" (Johnathan, WISP) being linked to its large Traveller population, they did not report feeling fearful. This is likely because they had grown up in areas where there was a high concentration of Travellers, so they had "real world" experiences with the community. 
Both staff and student participants viewed their school as one in which academic expectations were low, with the student participants very conscious of what was thought about students who attended this school, and that it was "full of dummies" (Josef, MSP). Many of the student participants seemed to have internalised these negative and deficit perceptions of their academic ability; for example, Marian (MSP) and Jason (WISP) displayed a concerning lack of confidence in their own ability and believed that they were "not smart". Similarly, Holly (MSP) and Josef (MSP) had been forced to confront issues of being considered inferior, and while they challenged the negative stereotypes ascribed to them, their level of critical insight was limited as they both indicated that they saw themselves as "exceptions". For example, Josef (MSP) remarked that while some of the students in St. Greg's fit the stereotypes ascribed to them, he stated that it was "not all of them". When certain groups are pathologized, they may internalise the dominant narrative as the "truth" and these internalised negative beliefs often result in self-fulfilling prophecies of failure [88]. Hollingworth and Archer [81] found that minority students must negotiate their identities when they are associated with a school labelled negatively. They remind us that the pathologisation of urban schools can have damaging effects on the students that attend them, including on the ways in which students see themselves (ibid.). Reay [89] explains that there is a painful struggle involved in trying to separate out from the "demonised other" because it is so tied up with the self.

Research has found that teachers generally tend to underestimate the academic ability of certain minority student groups [90]. The literature highlights how some teachers understand educational disadvantage through a cultural deficit lens, tending to blame them and/or their parents for their low levels of educational attainment [91]. Such deficit views lead to lowered teacher expectations and the pathologisation of students from disadvantaged backgrounds [92]. This was evident in the current study with the SPs explaining that as a teacher in St. Greg's, one had to lower one's expectations. The SPs were aware that in urban DEIS schools like St. Greg's, many of the students come from communities experiencing significant socio-economic disadvantage [10]. Indeed, the staff highlighted that many of the students at St. Greg's had experienced adverse childhood experiences, such as witnessing domestic violence, addiction, and substance abuse, having family members incarcerated, homelessness, and experiencing neglect. Although the SPs understood that many of St. Greg's students had had such experiences, they still attributed their poor engagement to a lack of motivation or "aspirations" (John, SP). Yet, research has found that having to deal with such significant and ongoing life challenges inevitably results in education being less prioritised. As Doyle and Keane ([93], p. 83) found, for those from marginalised backgrounds, "having to cope with frequent and significant life traumas and fighting to survive everyday life in their lived realities, seriously constrained educational engagement".

The SPs negatively compared Travellers to "most parents" (Sarah, SP), positioning them as "different" in terms of the value that they attached to education. While the belief that Travellers do not value education or promote it in the home is generally accepted in Irish society, research has found that Traveller parents are very receptive to their children's education [5]. Myers, McGhee, and Bhopal [94] found that changing social circumstances had led to Traveller parents increasingly seeing the importance of formal education for their children in terms of them being able to make a living in the modern world. While some Traveller parents may have low expectations for their children [39], this needs to be understood in the context of the structural inequalities pervasive in society in relation to poverty and racism, and the major barriers within the education system and labour market, which understandably frame Traveller parents' perspectives [39].

\subsection{Issues of School "Choice"}

From the participants' perspectives, choosing St. Greg's was related to having a family history of attending the school, not being able to access other schools, and the school providing supports and 'freebies'. There were differences between the student participant 
groups regarding their "choice" of St. Greg's. School choice was influenced and constrained by students' (and their families') perceptions of where they would "have a better chance of getting in" (Jason, WISP). In their discussion about "choosing" St. Greg's, many of the (non-Traveller) minority ethnic and White Irish student participants noted that they had not been able to access other schools. Indeed, most of the latter group expressed a desire to attend different schools, somewhere that "they actually have to try to educate you" (Jason, WISP), demonstrating a belief that the standard of education at St. Greg's was inferior to that in other schools.

Not being able to access other schools needs to be considered in the context of schools' admissions policies in Ireland, and staff and student participants were clear that schools had different approaches. St. Greg's was reported by staff and student participants as having an inclusive policy and practice compared to other schools who "cherry- picked" (Padraic, $\mathrm{SP}$ ), did not "take their fair share" (John, SP) of students from diverse backgrounds, and paid "lip service to open door policies" (Clodagh, SP). However, the school was in no position to be choosy: student enrolment had been declining for some years. Student enrolment in DEIS schools is often lower than enrolment in non-DEIS schools, which are often over-subscribed [83]. Some of the SPs felt some (particularly over-subscribed) schools employed certain "elitist" (Padraic, SP) practices (including the requirement of payment for certain extra-curricular activities) as an exclusive mechanism resulting in students from disadvantaged backgrounds being unable to access those schools. In this way, some schools are a "closed shop" and may covertly discriminate against certain groups [2]. As the current system is seen to be functional (for some), and serves the needs of the majority, such practices, which directly or indirectly result in the exclusion of minorities, are often unquestioned [95]. In such a climate, institutional racism is normalised and selection procedures which disadvantage ethnic minority students are considered acceptable [73].

In contrast to the other student participants, the Traveller student participants were clear that they preferred St. Greg's to other schools because of the high number of Travellers. Wanting to be around people like oneself is unsurprising; drawing on theories of social homophily [96], Keane [97] argued that homophilous groups facilitate an important selfprotective function in the provision of a sense of comfort, security, and safety. Bhopal and Myers [27] also found that Travellers felt more comfortable in spaces where they were surrounded by their own. Similarly, Boyle et al. [5] found that the Traveller parents who participated in their study felt at ease in all-Traveller preschools because they felt a sense of belonging. This apparent self-segregation suggests that they would not have felt comfortable in spaces where they constituted a minority. However rational this inclination and behaviour may be on the part of Traveller families and students, what seems like choice here is an inevitability of living in a society where being different is viewed as an aberration and is met with hostility. It also clearly calls into question the inaction of the education system in making all schools comfortable and safe spaces for all students, including Traveller students.

The issue of access to additional supports and 'freebies' was also of note in the participants' discussions about students' reasons for choosing St. Greg's. Due to their designated disadvantaged status, DEIS schools are allocated additional resources and can offer additional supports for students and their families, including learning supports, free school meals, and free books [11]. In this study, the SPs assumed that these "advantages" were what motivated Traveller parents to choose St. Greg's, demonstrating the prevalent societal stereotype of Travellers as a group who prefer to live on state "hand-outs [98] and do not wish to work [99] among the teacher participants. Further, as over half of Traveller children attend non-DEIS schools [20], this assumption is clearly questionable. Teachers are rarely given the opportunity to interrogate their deeply ingrained beliefs about the Travelling community (or other marginalised communities), and therefore it is not surprising that negative stereotypes may be deeply ingrained within their psyche.

While previous research has highlighted the complexities of choice and decisionmaking for (non-Traveller) minority ethnic and lower socio-economic groups, this study 
contributes to our understanding of the complex factors impacting Traveller families and young people in this domain, as well as in comparison to those from other ethnic groups. As was shown, in this DEIS school, the student population was highly diverse, with very high concentrations of students from non-Traveller minority ethnic, Traveller, and lower socio-economic groups. High concentrations of disadvantage within school populations exacerbate patterns of inequality in education $[83,100,101]$. The segregation evident between DEIS and non-DEIS schools, and even amongst DEIS schools in relation to more concentrated levels of disadvantage, raises important questions about the extent to which the DEIS system is reproducing the existing social order rather than addressing educational disadvantage, which is purportedly the aim. While the system needs to seriously examine how less segregated schools may be facilitated, there is also a need to better support teachers to effectively teach in DEIS schools, so that they may better support students from minority and disadvantaged backgrounds. Additionally, DEIS schools need to be adequately resourced if they are to tackle, and indeed avoid perpetuating, educational disadvantage [82].

Author Contributions: Conceptualization, H.M.G. and E.K.; methodology, H.M.G. and E.K.; formal analysis, H.M.G. and E.K.; writing—original draft preparation, H.M.G. and E.K.; writing-review and editing, H.M.G. and E.K.; supervision, E.K.; project administration, H.M.G. and E.K.; funding acquisition, H.M.G. and E.K. All authors have read and agreed to the published version of the manuscript.

Funding: This research was funded by the Irish Research Council Postgraduate Scholarship Programme, the National University of Ireland, Galway Doctoral Fellowship, and the National University of Ireland, Mary L. Thornton Scholarship in Education.

Institutional Review Board Statement: Full ethical approval for the study was granted by the National University of Ireland, Galway Research Ethics Committee (REC).

Informed Consent Statement: Informed consent was obtained from all participants involved in the study.

Data Availability Statement: Not applicable.

Conflicts of Interest: The authors declare no conflict of interest.

\section{References}

1. Equal Status Act 2000; Acts of the Oireachtas; Stationery Office: Dublin, Ireland, 2000.

2. Lodge, A.; Lynch, K. Diversity at School; Institute of Public Administration for the Equality Authority: Dublin, Ireland, 2004.

3. Tormey, T.; Gleeson, J. Irish post-primary students' attitudes towards ethnic minorities. Ir. Educ. Stud. 2012, 31, 157-173. [CrossRef]

4. Devine, D.; Kenny, M.; MacNeela, E. Naming the other-Children's construction and experience of racisms in Irish primary schools. Race Ethn. Educ. 2008, 11, 369-385. [CrossRef]

5. Boyle, A.; Flynn, M.; Hanafin, J. Optimism despite disappointment: Irish Traveller parents' reports of their own school experiences and their views on education. Int. J. Incl. Educ. 2018, 24, 1389-1409. [CrossRef]

6. Connolly, P.; Keenan, M. Racist Harassment in the White Hinterlands: Minority ethnic children and parents' experiences of schooling in Northern Ireland. Br. J. Sociol. Educ. 2002, 23, 341-355. [CrossRef]

7. Hourigan, N.; Campbell, M. The TEACH Report: Traveller Education and Adults: Crisis Challenge and Change; National Association of Travellers' Centres: Athlone, Ireland, 2010.

8. Weir, S.; Archer, P.; O'Flaherty, A.; Gilleece, L. A Report on the First Phase of the Evaluation of DEIS; Educational Research Centre: Dublin, Ireland, 2011.

9. Department of Education and Science. Delivering Equality of Opportunity in Schools (DEIS): An Action Plan for Educational Inclusion; DES: Dublin, Ireland, 2005.

10. Kavanagh, L.; Weir, S.; Moran, E. The Evaluation of DEIS: Monitoring Achievement and Attitudes among Urban Primary School Pupils from 2007 to 2016; Educational Research Centre: Dublin, Ireland, 2017.

11. Watson, D.; Kenny, O.; McGinnity, F.; Russell, H. A Social Portrait of Travellers in Ireland, Research Series; ESRI Publications: Dublin, Ireland, 2017; Volume 56, pp. 589-608.

12. Central Statistics Office. Census of Population 2016: Profile 8 Irish Travellers, Ethnicity and Religion; Central Statistics Office: Dublin, Ireland, 2017.

13. Central Statistics Office. Profile 7, Religion, Ethnicity and Irish Travellers; Stationery Office: Dublin, Ireland, 2012. 
14. Department of Education and Skills (DES) and Higher Education Authority (HEA). Progress Review of the National Access Plan and Priorities to 2021; HEA: Dublin, Ireland, 2018.

15. Department of Education and Skills (DES). Action Plan for Increasing Traveller Participation in Higher Education 2019-2021; Department of Education and Skills: Dublin, Ireland, 2019.

16. Byrne, D.; McGinnity, F.; Smyth, E.; Darmody, M. Immigration and school composition in Ireland. Ir. Educ. Stud. 2010, 29, 271-288. [CrossRef]

17. Devine, D. Immigration and Schooling in the Republic of Ireland-Making a Difference? Manchester University Press: Manchester, UK, 2011.

18. Mc Ginley, H. A Critical Exploration of Intercultural Education in a Post-primary School in Ireland with Particular Reference to Travellers. Ph.D. Thesis, National University of Ireland, Galway, Ireland, 2020.

19. Ní Dhuinn, M.; Keane, E. But you don't look Irish: Identity constructions of minority ethnic students as 'non-Irish' and deficient learners at school in Ireland. Int. Stud. Sociol. Educ. 2021, 1-30. [CrossRef]

20. Darmody, M.; Byrne, D.; McGinnity, F. Cumulative disadvantage? Educational careers of migrant students in Irish secondary schools. Race Ethn. Educ. 2012, 17, 129-151. [CrossRef]

21. Kitching, K. Interrogating the changing inequalities constituting popular 'deviant' and ordinary subjects of school/subculture in Ireland: Moments of new migrant student recognition, resistance and recuperation. Race Ethn. Educ. 2011, 14, 293-311. [CrossRef]

22. Chapman, T.K.; Bhopal, K. The perils of integration: Exploring the experiences of African American and black Caribbean students in predominantly white secondary schools. Ethn. Racial Stud. 2019, 42, 1110-1129. [CrossRef]

23. Castro, A.J. Themes in the research on preservice teachers views of cultural diversity: Implications for researching millennial preservice teachers. Educ. Res. 2010, 39, 198-210. [CrossRef]

24. Troyna, B. Can you see the Join? An Historical Analysis of Multicultural and Antiracist Education Policies. In 'Race', Education and Society: Structures and Strategies; Dawn, G., Mayor, B., Blair, M., Eds.; SAGE Publications: London, UK, $1992 ;$ pp. 63-91.

25. Youdell, D. Identity traps, or how black students fail: The interactions between biographical, sub-cultural and learner identities. Br. J. Soc. Educ. 2003, 24, 3-20. [CrossRef]

26. Peguero, A. Violence, schools, and dropping out: Racial and ethnic disparities in the educational consequence of student victimisation. J. Interpers. Violence 2011, 26, 3753-3772. [CrossRef]

27. Bhopal, K.; Myers, M. Marginal groups in marginal times: Gypsy and Traveller parents and home education in England, UK. Br. Educ. Res. J. 2015, 42, 5-20. [CrossRef]

28. Monroe, C.R. Why Are "Bad Boys" always Black? Causes of Disproportionality in School Discipline and Recommendations for Change. Clear. House J. Educ. Strat. Issues Ideas 2005, 79, 45-50. [CrossRef]

29. Devine, D. Welcome to the Celtic Tiger? Teacher responses to immigration and increasing ethnic diversity in Irish schools. Int. Stud. Sociol. Educ. 2005, 15, 49-69. [CrossRef]

30. Fine-Davis, M.; Faas, D. Equality and Diversity in the Classroom: A Comparison of Students' and Teachers' Attitudes in Six European Countries. Soc. Indic. Res. 2014, 119, 1319-1334. [CrossRef]

31. Darmody, M.; Smyth, E.; Byrne, D.; McGinnity, F. New School, New System: The Experiences of Immigrant Students in Irish Schools. In International Handbook of Migration, Minorities and Education; Springer: Dordrecht, The Netherlands, 2012; pp. 283-299.

32. Nowlan, E. Underneath the Band-Aid: Supporting bilingual students in Irish schools. Ir. Educ. Stud. 2008, 27, 253-266. [CrossRef]

33. Tatum, B.D. Why Are all the Black Kids Sitting Together in the Cafeteria? And Other Conversations about Race; Basic Books: New York, NY, USA, 2017.

34. Rhamie, J.; Bhopal, K.; Bhatti, G. Stick to your own kind: Pupils' Experiences of Identity and Diversity in Secondary Schools. Br. J. Educ. Stud. 2012, 60, 171-191. [CrossRef]

35. Peguero, A.; Jiang, X. Backlash for breaking racial and ethnic breaking stereotypes: Adolescent school victimization across contexts. J. Interpers. Violence 2016, 31, 1047-1073. [CrossRef]

36. Raby, R. There's no racism at my school, it's just joking around: Ramifications for anti-racist education. Race Ethn. Educ. 2004, 7, 367-383. [CrossRef]

37. Ní Laoire, C.; Bushin, N.; Carpena-Mendez., F.; White, A. Tell Me about Yourself: Migrant Children's Experiences of Moving to and Living in Ireland; University College Cork: Cork, Ireland, 2009.

38. Kiddle, C. Partnerships depend on power-sharing: An exploration of the relationships between Fairground and Gypsy Traveller parents and their children's teachers in England. Int. J. Educ. Res. 2000, 33, 265-274. [CrossRef]

39. Derrington, C. Fight, flight and playing white: An examination of coping strategies adopted by Gypsy Traveller Adolescents in English secondary schools. Int. J. Educ. Res. 2007, 46, 357-367. [CrossRef]

40. Bhopal, K.; Myers, M. Insiders, Outsiders and Others: Gypsies and Identity; University of Hertfordshire Press: Hatfield, UK, 2008.

41. Bhopal, K. This is a school, it's not a site: Teachers' attitudes towards Gypsy and Traveller pupils in schools in England, UK. Br. Educ. Res. J. 2011, 37, 465-483. [CrossRef]

42. Donahue, M.; McVeigh, R.; Ward, M. Misli, Crush, Mislì: Irish Travellers and Nomadism: A Research Report for the Irish Traveller Movement and Traveller Movement Northern Ireland. 2005. Available online: https://itmtrav.ie/wp-content/uploads/2016/11/ MISLI-CRUSH-MISLI-Irish-Travellers-and-Nomadism.pdf (accessed on 11 May 2021).

43. Cudworth, D. Gypsy/Traveller Culture and the Schooling Process. In Schooling and Travelling Communities; Palgrave Macmillan: Cham, Switzerland, 2018; pp. 131-166. [CrossRef] 
44. Derrington, C.; Kendall, S. Gypsy Traveller Students in Secondary Schools: Culture, Identity and Achievement; Trentham Books: Stoke-on-Trent, UK, 2004.

45. Kavanagh, A.M. Emerging Models of Intercultural Education in Irish Primary Schools: A Critical Case Study Analysis. Ph.D. Thesis, St. Patrick's College, Dublin City University, Dublin, Ireland, 2013.

46. Deuchar, R.; Bhopal, K. We're still human beings, we're not aliens: Promoting the citizenship rights and cultural diversity of Traveller children in schools: Scottish and English perspectives. Br. Educ. Res. J. 2013, 39, 733-750. [CrossRef]

47. Lloyd, G.; Stead, J. The boys and girls not calling me names and the teachers to believe me': Name calling and the experiences of Travellers in Scotland. Child. Soc. 2001, 15, 361-374. [CrossRef]

48. Helms, J.E. An Update of Helm's White and People of Color Racial Identity Models. In Versions Were Presented at the Psychology and Societal Transformation Conference, U Western Cape, South Africa, Jan 1994, and at a Workshop Entitled "Helm's Racial Identity Theory," Annual Multicultural Winter Roundtable, Teachers Coll-Columbia U; Sage Publications, Inc.: New York, NY, USA, 1995.

49. Lynch, K.; Lodge, A. Equality and Power in Schools: Redistribution, Recognition and Representation; Routledge/Falmer: London, UK, 2002.

50. Kitching, K. How the Irish became CRT'd? 'Greening' Critical Race Theory, and the pitfalls of a normative Atlantic state view. Race Ethn. Educ. 2015, 18, 163-182. [CrossRef]

51. Bryan, A. You've got to teach people that racism is wrong and then they won't be racist: Curricular representations and young people's understandings of race and racism. J. Curric. Stud. 2012, 44, 599-629. [CrossRef]

52. Kavanagh, A.M.; Dupont, M. Making the invisible visible: Managing tensions around including Traveller culture and history in the curriculum at primary and post-primary levels. Ir. Educ. Stud. 2021, 40, 553-569. [CrossRef]

53. Faas, D.; Sokolowska, B.; Darmody, M. Everybody is Available to Them: Support Measures for Migrant Students in Irish Secondary School. Br. J. Educ. Stud. 2015, 63, 447-466. [CrossRef]

54. Skeggs, B. Exchange, value and affect: Bourdieu and 'the self'. Sociol. Rev. 2004, 52, 75-95. [CrossRef]

55. Byrne, D.; Smyth, E. No Way Back? The Dynamics of Early School Leaving; The Liffey Press in Association with the Economic and Social Research Institute (ESRI), National Council for Curriculum and Assessment (NCCA) and Department of Education and Science (DES): Dublin, Ireland, 2010.

56. Ball, S.J.; Davies, J.; David, M.; Reay, D. "Classification" and "judgement": Social class and the "cognitive structures" of choice of higher education. Br. J. Sociol. Educ. 2002, 23, 51-72. [CrossRef]

57. Lundy, L. Human Rights and Equality Litigation in Northern Ireland's Schools. Educ. Law J. 2004, 5, 82.

58. Levinson, M.P. Literacy in English Gypsy Communities: Cultural Capital Manifested as Negative Assets. Am. Educ. Res. J. 2007, 44, 5-39. [CrossRef]

59. Parker-Jenkins, M.; Masterson, M. No longer 'Catholic, White and Gaelic': Schools in Ireland coming to terms with cultural diversity. Ir. Educ. Stud. 2013, 32, 477-492. [CrossRef]

60. Kelly, N.; Fleming, F.; Demirel, B.; O’Hara, J. The Real Cost of School 2020: Back to School Survey Briefing Paper; Barnardos: Dublin, Ireland, 2020.

61. Heffernan, B. Traveller Loses His Appeal over School's Preference for Past Pupils' Children. Irish Independent, 4 February 2012.

62. Ball, S.J.; Vincent, C. I Heard it on the Grapevine: 'Hot' knowledge and school choice. Br. J. Sociol. Educ. 1998, 19, 377-400. [CrossRef]

63. Thrift, N. 'Us' and 'Them': Re-Imagining Places, Re-Imagining Identities, in Consumption and Everyday Life; MacKay, H., Ed.; Open University Press: Milton Keynes, UK, 1997; pp. 159-212.

64. McAvinue, L.; Weir, S. The Evaluation of DEIS at Post-Primary Level: An Update on Trends over Time in Achievement and Retention; Report to the Department of Education and Skills; Educational Research Centre: Dublin, Ireland, 2015.

65. Gilleece, L.; Nelis, S.M.; Fitzgerald, C.; Cosgrove, J. Reading, Mathematics and Science Achievement in DEIS Schools: Evidence from PISA; ERC: Dublin, Ireland, 2020.

66. Cohen, L.; Manion, L.; Morrison, K. Research Methods in Education, 8th ed.; Routledge: Abingdon, UK, 2018.

67. Guba, E.; Lincoln, Y. Paradigmatic Controversies, Contradictions, and Emerging Confluences. In The Sage Handbook of Qualitative Research, 3rd ed.; Denzin, N., Lincoln, Y., Eds.; Sage: Thousand Oaks, CA, USA, 2005; pp. 191-216.

68. Creswell, W.J. Research Design: Qualitative, Quantitative and Mixed Methods Approaches, 4th ed.; Sage Publications: Sauzend Oaks, CA, USA, 2014.

69. Bell, D.A.; Brown, V. Board of Education and the Interest-Convergence Dilemma. Harv. Law Rev. 1980, 93, 518. [CrossRef]

70. Crenshaw, K. Race, reform, retrenchment: Transformation and legitimation in anti-discrimination law. Harv. Law Rev. 1988, 101, 1331-1387. [CrossRef]

71. Delgado, R. Storytelling for oppositionists and others: A plea for narrative. Mich. Law Rev. 1989, 87, 2411-2441. [CrossRef]

72. Ladson-Billings, G. The evolving role of critical race theory in educational scholarship. Race Ethn. Educ. 2005, 8, 115-119. [CrossRef]

73. Delgado, R.; Stefancic, J. Critical Race Theory: An Introduction; NYU Press: New York, NY, USA, 2001.

74. Bhopal, K. White Privilege: The Myth of a Post-Racial Society; Policy Press: Bristol, UK, 2018.

75. Gillborn, D. Critical Race Theory and Education: Racism and anti-racism in educational theory and praxis. Discourse Stud. Cult. Politics Educ. 2006, 27, 11-32. [CrossRef]

76. Calhoun, C. Critical Social Theory: Culture, History and the Challenge of Difference; Blackwell Publishing: Malden, MA, USA, 1995. 
77. Parker, L.; Lynn, M. What's Race Got to Do with It? Critical Race Theory's Conflicts with and Connections to Qualitative Research Methodology and Epistemology. Qual. Inq. 2002, 8, 7-22. [CrossRef]

78. Bayoumi, A.; Hwang, S. Methodological, Practical, and Ethical Challenges to Inner-City Health Research. J. Urban Health Bull. N. Y. Acad. Med. 2003, 79, S35-S42. [CrossRef] [PubMed]

79. Charmaz, K. Grounded Theory Methods in Social Justice Research. In The Sage Handbook of Qualitative Research, 4th ed.; Denzin, L., Ed.; Sage: Thousand Oaks, CA, USA, 2011; pp. 359-380.

80. Petty, N.J.; Thomson, O.P.; Stew, G. Ready for a paradigm shift? Part 1: Introducing the philosophy of qualitative research. Man. Ther. 2012, 17, 267-274. [CrossRef] [PubMed]

81. Hollingworth, S.; Archer, L. Urban schools as urban places: School reputation, children's identities and engagement with education in London. Urban Stud. 2010, 47, 584-603. [CrossRef]

82. Fleming, B.; Harford, J. The DEIS programme as a policy aimed at combating educational disadvantage: Fit for purpose? Ir. Educ. Stud. 2021, 1-19. [CrossRef]

83. Smyth, E.; McCoy, S.; Kingston, G. Learning from the Evaluation of DEIS; ESRI: Dublin, Ireland, 2015.

84. Devine, D. Valuing children differently? Migrant children in education. Child. Soc. 2013, 27, 282-294. [CrossRef]

85. Bryan, A.; Bracken, M. They Think the Book is Right and I am Wrong Intercultural Education and the Positioning of Ethnic Minority Students in the Formal and Informal Curriculum. In Exploring the Lives of Immigrant and Ethnic Minority Children; Darmody, M., Tyrrell, N., Song, S., Eds.; Sense Publications: Dublin, Ireland, 2011; pp. 105-123.

86. Cahill, K.; Hall, K. Choosing schools: Explorations in post-primary school choice in an urban Irish working class community. Ir. Educ. Stud. 2014, 33, 383-397. [CrossRef]

87. Bryan, A. Corporate multiculturalism, diversity management, and positive interculturalism in Irish schools and society. Ir. Educ. Stud. 2010, 29, 253-269. [CrossRef]

88. Herrnstein, R.J.; Murray, C.A. The Bell Curve: Reshaping of American Life by Differences in Intelligence; Free Press: New York, NY, USA; London, UK, 1994.

89. Reay, D. Mostly Roughs and Toughs: Social Class, Race and Representation in Inner City Schooling. Sociology 2004, 38, 1005-1023. [CrossRef]

90. Fine, M.; Weis, L. Silenced Voices and Extraordinary Conversations: Re-Imagining Schools; Teachers College Press: New York, NY, USA, 2004.

91. Cochran-Smith, M. Color blindness and basket making are not the answers: Confronting the dilemmas of race, culture, and language diversity in teacher education. Am. Educ. Res. J. 1995, 32, 493-522. [CrossRef]

92. White, C.M. Deficit thinking redux: Cultural deficit discourse and an urban community and school in Fiji. Soc. Identities 2014, 20, 155-170. [CrossRef]

93. Doyle, G.; Keane, E. 'Education comes second to surviving': Parental perspectives on their children's early school leaving in an area challenged by marginalisation. Ir. Educ. Stud. 2019, 38, 71-88. [CrossRef]

94. Myers, M.; McGhee, D.; Bhopal, K. At the crossroads: Gypsy and Traveller parents' perceptions of education, protection and social change. Race Ethn. Educ. 2010, 13, 533-548. [CrossRef]

95. O'Brien, S.; Fathaigh, M. Ideological challenges to the social inclusion agenda in the Republic of Ireland. Int. J. Incl. Educ. 2007, 11, 593-606. [CrossRef]

96. McPherson, M.; Smith-Lovin, L.; Cook, J. Birds of a feather: Homophily in social networks. Annu. Rev. Sociol. 2001, 27, 415-444. [CrossRef]

97. Keane, E. Distancing to self-protect: The perpetuation of inequality in higher education through socio-relational dis/engagement. Br. J. Sociol. Educ. 2011, 32, 449-466. [CrossRef]

98. McGee, H. 'Daily Mail' Column on Travellers Criticised by Equality Authority. The Irish Times. 2014. Available online: https:// www.irishtimes.com/news/social-affairs/daily-mail-column-on-travellers-criticised-by-equality-authority-1.1754911 (accessed on 15 August 2017).

99. Mac Gréil, M. Pluralism and Diversity in Ireland; Columba Press: Dublin, Ireland, 2011.

100. Perry, L.B.; McConney, A. Does the SES of the school matter? An examination of socioeconomic status and student achievement using PISA 2003. Teach. Coll. Rec. 2010, 112, 1137-1162. [CrossRef]

101. Sofroniou, N.; Archer, P.; Weir, S. An Analysis of the Association between Socioeconomic Context, Gender, and Achievement. Ir. J. Edu./Iris Eireannach Oideachais 2004, 35, 58-72. 